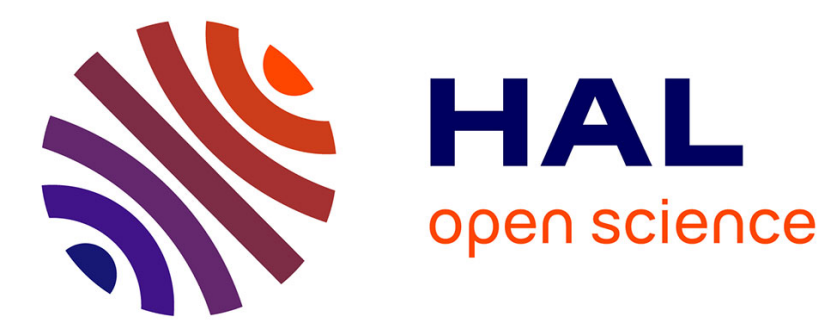

\title{
A review on combined effects of moniliformin and co-occurring Fusarium toxins in farm animals
}

J-M Fremy, Imourana Alassane-Kpembi, Isabelle P. Oswald, B. Cottrill, H.P. van Egmond

\section{To cite this version:}

J-M Fremy, Imourana Alassane-Kpembi, Isabelle P. Oswald, B. Cottrill, H.P. van Egmond. A review on combined effects of moniliformin and co-occurring Fusarium toxins in farm animals. World Mycotoxin Journal, 2019, 12 (3), pp.281-291. 10.3920/WMJ2018.2405 . hal-02627929

\section{HAL Id: hal-02627929 \\ https://hal.inrae.fr/hal-02627929}

Submitted on 2 Sep 2021

HAL is a multi-disciplinary open access archive for the deposit and dissemination of scientific research documents, whether they are published or not. The documents may come from teaching and research institutions in France or abroad, or from public or private research centers.
L'archive ouverte pluridisciplinaire HAL, est destinée au dépôt et à la diffusion de documents scientifiques de niveau recherche, publiés ou non, émanant des établissements d'enseignement et de recherche français ou étrangers, des laboratoires publics ou privés.

\section{(1)(1) 8 (2)}

Distributed under a Creative Commons Attribution - NonCommercial - ShareAlikel 4.0 


\title{
A review on combined effects of moniliformin and co-occurring Fusarium toxins in
}

\section{farm animals}

\author{
J.-M. Fremy ${ }^{1}$, I. Alassane-Kpembi ${ }^{2,3}$, I.P. Oswald ${ }^{3}$, B. Cottrill ${ }^{4}$ and H.P. Van Egmond ${ }^{5 *}$ \\ ${ }^{1}$ Retired, 10 rue Labrousse, 92160 Antony, France; ${ }^{2}$ Hôpital d'Instruction des Armées - Centre Hospitalier Universitaire \\ Cotonou Camp Guézo, Cotonou 01BP517, Benin; ${ }^{3}$ Toxalim Research Center in Food Toxicology, Université de Toulouse, \\ INRA, ENVT, INP-Purpan, UPS, 180 Chemin de Tournefeuille, 31027 Toulouse, France; ${ }^{4}$ Retired, 34 Danescourt Road, \\ Wolverhampton, WV6 9BG, United Kingdom; ${ }^{5}$ Retired, Willem de Zwijgerlaan 17, 3722 JR, Bilthoven, the Netherlands; \\ hp.van.egmond@planet.nl
}

Received: 12 November 2018 / Accepted: 17 May 2019

(c) 2019 Wageningen Academic Publishers

OPEN ACCESS CC) (i) (ㄱ)

REVIEW ARTICLE

\begin{abstract}
Co-occurrence of mycotoxins in food and feed represents the rule rather than the exception. Information about combinatory toxic effects of co-occurring mycotoxins is scarce, in particular the effects that mixtures of mycotoxins in feed may have on farm animals. This review focusses on studies on the combined effects of moniliformin and co-occurring mycotoxins in feed on farm animals. Moniliformin is a mycotoxin of emerging scientific interest, which may co-occur with many other mycotoxins, especially Fusarium mycotoxins. Oral exposure to moniliformin reduces feed consumption and body weight gain in poultry, in pigs and catfish, and induces cardiotoxic effects and/or alterations in serum biochemical and haematological parameters. In this review only experiments comparing effects as a result of the exposure to a combination of mycotoxins with effects due to the exposure to single mycotoxins were considered. Identified published studies on combined toxicity have been limited to combinations of moniliformin with either fumonisin $\mathrm{B}_{1}$ or deoxynivalenol, and were performed with poultry, pigs, and catfish. Most of the moniliformin/fumonisin $\mathrm{B}_{1}$ investigations involved poultry and focussed on adverse effects on feed intake, weight gain and immune response, as well as organ lesions. These studies mainly reported an interactive toxicity of moniliformin and fumonisin $B_{1}$ but did not allow identification of the type of interaction. Likewise, no indication could be given for the interaction detected for both mycotoxins on weight gains of catfish. For the moniliformin/deoxynivalenol combination, only one study with broiler chickens was found relevant. This study concluded additive or less than additive toxicity, using kidney lesions and renal tubular epithelial degeneration as endpoints. While possible interactions between moniliformin and fumonisin $B_{1}$ or deoxynivalenol were identified, the conclusions are based on limited studies and experimental designs. Further studies on the combined toxicity of moniliformin with other mycotoxins and other animal species would be needed.
\end{abstract}

Keywords: deoxynivalenol, fumonisin $\mathrm{B}_{1}$, adverse effects, feed, risk assessment

\section{Introduction}

The presence of multiple mycotoxins in food and feed represents the rule rather than the exception. Cooccurrence of mycotoxins may be due to the ability of certain fungal species to produce several toxins, and to the possibility of co-occurrence of different mycotoxinproducing species in the same substrate. The likelihood of co-occurring mycotoxins in food and feed is challenging for risk assessment, since recognised procedures of risk assessment on a chemical-by-chemical basis are in danger of underestimating the risk of chemicals to health where combined exposure occurs (EFSA, 2013, 2019; Kortenkamp et al., 2009; Meek et al., 2011). The scientific interest in the toxicity of mixtures of mycotoxins is increasing rapidly (Alassane-Kpembi et al., 2017a; Assunção et al., 2016). As far as mycotoxins are concerned, the simultaneous exposure to different compounds has been shown to result in antagonistic, additive or synergistic effects (AlassaneKpembi et al., 2017a; Grenier and Oswald, 2011). A 
demonstration of synergism would legitimately heighten concerns about health risks (Alassane-Kpembi et al., 2017b), while the implications of additive combination effects have received only limited attention. Indeed, the threshold dose for toxic effects may sometimes be exceeded in the presence of exposure to a mixture, although the exposure to each single compound is unlikely to pose risk (Silva et al., 2002).

The issue of combined toxicity of mycotoxins is very complex, since many mycotoxins may co-occur. Even restriction down to certain specific groups of fungi and the mycotoxins they may produce, poses a major problem in risk assessment. One of the most important groups of fungi known to produce multiple mycotoxins are the Fusarium species which can frequently infect small grain cereals and maize. Many toxigenic Fusarium species exist, and they may produce a wide array of mycotoxins. It was therefore considered appropriate to address the issue of the combined toxic effects of co-occurring Fusarium toxins, particularly since the importance of this was noted during the drafting of EFSA Scientific Opinions on the risks to human and animal health related to the presence of various Fusarium mycotoxins in food and feed. This was particularly the case for the Opinion on moniliformin (MON), a mycotoxin of increasing scientific interest (EFSA, 2018). During the preparation of these Opinions, information on the cooccurrence and the combined effects of MON and other Fusarium mycotoxins was gathered, although it was only marginally reflected in the EFSA Opinion because it was considered of minor importance for the derivation of the health-based guidance value. Therefore, this paper brings together and reviews the information available with the aim of contributing to and stimulating scientific debate on the combined toxicology of mycotoxins, with particular reference to MON. In doing so, the authors have limited the scope of the paper to co-occurrence in feed and combined effects in farm animals, since there were no data on the combined effects of MON in experimental animals.

MON was first described by Cole et al. (1973) while screening for toxigenic metabolites of Fusarium moniliforme from naturally infected southern leaf blight-damaged maize seed. Since then, MON has been reported to be produced by several Fusarium species (Sydenham et al., 1996), including Fusarium avenaceum, Fusarium subglutinans and Fusarium proliferatum, and by Penicillium melanoconidium (HallasMøller et al., 2016). Some of these Fusarium species are also known to produce mycotoxins other than $\mathrm{MON}$, including beauvericin (BEA), enniatins (ENNs) and fumonisins B (FBs) (Gupta et al., 1991). In addition, Fusarium fujikuroi, which is a complex of several Fusarium species, was reported to produce not only $\mathrm{MON}$, but also $\mathrm{FB}_{1}, \mathrm{FB}_{2}$ and $\mathrm{FB}_{3}, \mathrm{BEA}$ and fusaproliferin (Fotso et al., 2002; Leslie et al., 1996). Darnetty and Salleh (2013) analysed twenty selected strains of Fusarium species, including Fusarium verticillioides, F. proliferatum, F. subglutinans and Fusarium konzum; all strains were found to have the ability to produce $\mathrm{FB}_{1}$ and/ or $\mathrm{MON}$ and/or BEA.

A limited number of studies on $\mathrm{MON}$ which focus on cooccurring mycotoxins in food and feed grains (samples taken from 2000 onwards, focus on European studies) have been selected and the results were summarised in Supplementary Table S1. This table is not meant to be comprehensive, but it illustrates how MON may co-occur with other mycotoxins in grains.

Based on the evidence that MON can co-occur with other mycotoxins in cereal grains, and in particular Fusarium mycotoxins, this paper, after summarising the state of knowledge on toxicological data of MON, and specifically the adverse effects on farm animals, reviews toxicity studies on the combined effects of MON with other Fusarium toxins.

\section{Toxicity of moniliformin}

Two recent review articles compiled data regarding the mechanism of action of MON and its in vitro and in vivo toxicity for laboratory animals (Freayman et al., 2017; Gruber-Dorninger et al., 2017). By inactivating enzymes sharing thiamin as a common cofactor (e.g. pyruvate dehydrogenase and $\alpha$-ketoglutarate dehydrogenase), MON impairs the Krebs cycle and compromises cellular energy supply.

The in vitro toxicity of $\mathrm{MON}$ is highly cell line dependent. It shows no inhibitory effects on the proliferation of human white blood cell progenitors or human platelet progenitors, nor to chicken primary chondrocyte and macrophage. In contrast, the mycotoxin is cytotoxic to human red blood cell progenitors and to chicken primary splenocytes, and both cardiac and skeletal myocytes. By the intraperitoneal route, the $\mathrm{LD}_{50}$ values of $\mathrm{MON}$ have been reported as 2.2$2.8 \mathrm{mg} / \mathrm{kg}$ body weight (bw) in 9-month-old female mink, and as 20.9 and $29.1 \mathrm{mg} / \mathrm{kg}$ bw in female and male mice, respectively, compared to 41.6 and $50.0 \mathrm{mg} / \mathrm{kg}$ bw by oral route in female and male rats.

In farm animals, the in vivo toxicity of MON targets the heart, causing acute heart failure, but the mycotoxin can also cause muscle weakness, respiratory distress and negatively affect immunity and animal performance. Accordingly, the massive increase of the number of mitochondria associated with the disruption of heart muscle fibres observed in Japanese quail and in broilers appears to be a compensatory event for the MON-induced decrease of cellular energy (Javed et al., 2005; Sharma et al., 2012; Thiel, 1978).

The addition of MON-contaminated material to diets from culture of toxigenic Fusarium strains, or purified MON from such culture material, has been used for the 
identification of adverse effects of MON in farm animals. Broiler chickens showed reduced body weight gain and cardiomyopathy, at exposure levels starting from $50 \mathrm{mg}$ $\mathrm{MON} / \mathrm{kg}$ feed during a 3-week experiment corresponding to a dose of $2.8 \mathrm{mg} \mathrm{MON} / \mathrm{kg}$ bw per day (Broomhead et al., 2002; Ledoux et al., 1995). Reduced feed intake, reduced body weight gain, cardiomegaly and changes in some haematological parameters, including increased alanine transferase and aspartate transaminase activities, creatinine concentration and decreased mean corpuscular volume, and mean corpuscular haemoglobin concentration have been observed at a level of $100 \mathrm{mg} \mathrm{MON} / \mathrm{kg}$ feed by several authors (Harvey et al., 1997; Kubena et al., 1999). Body weight reduction and cardiomegaly were also reported for turkeys receiving $100 \mathrm{mg} \mathrm{MON} / \mathrm{kg}$ and $50 \mathrm{mg} \mathrm{MON} /$ $\mathrm{kg}$ feed, respectively (Bermudez et al., 1997; Broomhead et al., 2002), while $75 \mathrm{mg} \mathrm{MON} / \mathrm{kg}$ feed induced cardiomegaly in fattening ducks (Broomhead et al., 1996; Morris et al., 1997). Reduced egg production and body weight gain in laying hens have been observed with a diet containing $100 \mathrm{mg} \mathrm{MON} / \mathrm{kg}$ feed (Kubena et al., 1999). In pigs, reductions in body weight gain and feed consumption, alteration of haematologic and serum biochemical values, and increases in heart weight and hydropericardium have all been associated with oral administrations of $100 \mathrm{mg}$ $\mathrm{MON} / \mathrm{kg}$ feed (Harvey et al., 2001). No data on observed adverse effects were available for other farm animal species.

In summary, reductions of feed consumption and body weight gain, and/or cardiotoxicity, and/or alterations in serum biochemical analytes and hematologic values were the observed adverse effects of MON in some farm animal species. The lowest observed adverse effect levels (LOAELs) were determined at $100 \mathrm{mg} \mathrm{MON} / \mathrm{kg}$ feed for pigs and laying hens, $75 \mathrm{mg} \mathrm{MON} / \mathrm{kg}$ feed for ducks and $50 \mathrm{mg}$ MON for broiler chickens and turkeys. No data on observed adverse effects were available for other farm animal species.

\section{Combined effects of moniliformin with other Fusarium toxins}

\section{Selection of experimental studies}

Experimental studies reported in the scientific literature focusing on the effects of diets simultaneously contaminated both with MON and other Fusarium toxins in farm animals have adopted different experimental designs. While the experimental studies based only on a design in which feed is naturally multi-contaminated provide, in principle, the evidence for the combined adverse effects under practical animal husbandry conditions, they have not compared the effects of feed naturally multi-contaminated with feed naturally contaminated with MON alone. Moreover, it should be noted that in such studies the naturally contaminated feed is also likely to have also contained several other mycotoxins. Consequently, studies reporting effects due to mixtures of MON with several mycotoxins or with another Fusarium toxin but without involving trials using contaminated diets with single mycotoxins have not been considered in this review. Moreover, publications available only as symposia abstracts, and not followed by a full description of experiment details in the associated proceedings, have been also excluded from this review. Using these criteria, the publications available in the literature on combined toxicity have been selected and their data are summarised in Table 1. The experimental studies focused on combinations of $\mathrm{MON}$ plus $\mathrm{FB}_{1}$ and on MON plus deoxynivalenol (DON). They involved pigs and poultry, since toxicological and case studies had identified these species as being the most sensitive to $\mathrm{FB}_{1}$ and $\mathrm{DON}$ (as compared to other animal species such as cattle). Only one experiment was performed with fish. The results from these experimental studies are summarised below.

\section{Moniliformin and fumonisin $B_{1}$}

Harvey et al. (2002) fed four groups of six barrows (mean bw $11.1 \mathrm{~kg}$ ) with either a control diet or diets containing $100 \mathrm{mg} \mathrm{MON} / \mathrm{kg}$ of feed, $100 \mathrm{mg}$ of $\mathrm{FB}_{1}$ per $\mathrm{kg}$ of feed, or $100 \mathrm{mg}$ of $\mathrm{FB}_{1}$ plus $100 \mathrm{mg}$ of MON per $\mathrm{kg}$ of feed, for 28 days. Regarding the chosen levels, the authors reported that $100 \mathrm{mg} \mathrm{MON} / \mathrm{kg}$ feed was identified to cause body weight gain reductions and feed consumption and led to alterations of haematologic and serum biochemical values for pigs (Harvey et al., 2001), and levels of $100 \mathrm{mg}$ $\mathrm{FB}_{1} / \mathrm{kg}$ feed to induce kidney lesions, pulmonal oedema and hepatic disease and reduction of body weight gain in swine ${ }^{1}$. Ground culture materials from $F$. fujikuroi containing MON (at no more than $1.0 \%$ of the basal diet), and from $F$. verticillioides containing $\mathrm{FB}_{1}$ (at no more than $2.5 \%$ of the basal diet) substituted part of the ground maize in the diets to achieve the appropriate concentrations of $\mathrm{MON}$ and $\mathrm{FB}_{1}$. The total $\mathrm{FB}$ content determined by HPLC analysis was $100 \mathrm{mg} \mathrm{FB}_{1}$ plus $30 \mathrm{mg} \mathrm{FB}{ }_{2}$ and $9 \mathrm{mg} \mathrm{FB}$ per $\mathrm{kg}$ feed. Body weight gain, feed efficiency, serum biochemical analytes, and haematological values were adversely affected by the $\mathrm{FB}_{1}$ and the combined $\mathrm{MON} / \mathrm{FB}_{1}$ diets. The $\mathrm{MON}$ diet decreased body weight gain. Two barrows in the MON diet group, and two barrows in the combined $\mathrm{MON} / \mathrm{FB}_{1}$ diet group died during the first 6 days of the study. Mild to moderate lesions were observed microscopically in heart and lung tissues of the groups fed MON and combined $\mathrm{MON} / \mathrm{FB}_{1}$ and in liver tissues of the groups fed $\mathrm{FB}_{1}$ and combined $\mathrm{MON} / \mathrm{FB}_{1}$. Except for the mortality associated with the two diets containing MON, these effects remained unexplained despite investigations by the authors, which included necropsies. Clinical disease induced by the combined feeding of these two mycotoxins appeared to

\footnotetext{
${ }^{1}$ In the EFSA opinion on MON, a LOAEL of $5 \mathrm{mg} \mathrm{FB} / 1 / \mathrm{kg}$ feed was identified for pigs (EFSA, 2018).
} 
Table 1. Selected studies on possible combined effects between moniliformin (MON) and other Fusarium mycotoxins in farm animals. ${ }^{1}$

\begin{tabular}{|c|c|c|c|c|}
\hline $\begin{array}{l}\text { MON/tested mycotoxin } \\
\text { species (exposure period) }\end{array}$ & $\begin{array}{l}\text { Concentrations (MON/ } \\
\text { tested mycotoxin) } \\
\text { (mg/kg feed) }\end{array}$ & $\begin{array}{l}\text { Additive or synergistic } \\
\text { combined effects }^{2}\end{array}$ & Antagonistic combined effect ${ }^{2}$ & Reference \\
\hline MON/FB ${ }_{1}$ chicken (14 days) & 27 to 154 / 27 to 154 & $\begin{array}{l}\text { - alkaline phosphatase } \\
\text { - gamma glutamyl transferase } \\
\text { - aspartate aminotransferase } \\
\text { - lactate dehydrogenase } \\
\text { - cholesterol } \\
\text { - sodium } \\
\text { - red blood cell } \\
\text { - haemoglobin } \\
\text { - packed cell volume }\end{array}$ & & $\begin{array}{l}\text { Javed et al. (1993, } \\
\text { 1995); Hall et al. } \\
\text { (1995) }\end{array}$ \\
\hline MON/FB turkey (21 days) & $100 / 200$ & $\begin{array}{l}\text { - feed intake }(P) \\
\text { - relative weight (liver) } \\
\text { - aspartate aminotransferase }\end{array}$ & $\begin{array}{l}\text { - body weight gain } \\
\text { - mortality } \\
\text { - glucose } \\
\text { - lactate dehydrogenase }\end{array}$ & $\begin{array}{l}\text { Bermudez et al. } \\
\text { (1997) }\end{array}$ \\
\hline MON/FB pig (28 days) & $100 / 100$ & $\begin{array}{l}\text { - feed intake } \\
\text { - creatinine }(P) \\
\text { - number of red blood cells }\end{array}$ & $\begin{array}{l}\text { - body weight gain } \\
\text { - mortality } \\
\text { - glucose } \\
\text { - inorganic phosphorus } \\
\text { - aspartate aminotransferase, alkaline } \\
\text { phosphatase, lactate dehydrogenase, } \\
\text { gamma-glutamyltransferase } \\
\text { - total iron }\end{array}$ & Harvey et al. (2002) \\
\hline $\begin{array}{l}\text { MON/FB laying hens } \\
\text { (420 days) }\end{array}$ & $50 / 100$ & $\begin{array}{l}\text { - relative weight (pancreas) } \\
\text { - albumin } \\
\text { - aspartate aminotransferase } \\
\text { - mortality }\end{array}$ & $\begin{array}{l}\text { - cytokine } \\
\text { - relative weight (liver, kidney) } \\
\text { - uric acid } \\
\text { - egg production } \\
\text { - egg weight }\end{array}$ & Kubena et al. (1999) \\
\hline MON/FB chicken (21 days) & $100 / 200$ & $\begin{array}{l}\text { - relative weight (liver, kidney) } \\
\text { - albumin, total protein } \\
\text { - relative weight (kidney, liver) }\end{array}$ & $\begin{array}{l}\text { - feed intake } \\
\text { - mortality } \\
\text { - aspartate aminotransferase } \\
\text { - body weight gain } \\
\text { - relative weight (heart, kidney, liver) } \\
\text { - albumin, total protein } \\
\text { - mortality } \\
\text { - aspartate aminotransferase } \\
\text { - relative weight (heart) } \\
\text { - feed intake, body weight gain } \\
\text { - mortality } \\
\text { - aspartate aminotransferase } \\
\text { - relative weight (heart) } \\
\text { - albumin } \\
\text { - mortality } \\
\text { - aspartate aminotransferase } \\
\text { - total protein }\end{array}$ & Ledoux et al. (2003) \\
\hline
\end{tabular}

be additive or less than additive and due primarily to the toxic expression of $\mathrm{FB}_{1}$. However, it should be noted that the total level of FBs was the sum of $\mathrm{FB}_{1}+\mathrm{FB}_{2}+\mathrm{FB}_{3}$, i.e. $139 \mathrm{mg} \mathrm{FBs} / \mathrm{kg}$ of feed. 
Table 1. Continued.

\begin{tabular}{|c|c|c|c|c|}
\hline $\begin{array}{l}\text { MON/tested mycotoxin } \\
\text { species (exposure period) }\end{array}$ & $\begin{array}{l}\text { Concentrations (MON/ } \\
\text { tested mycotoxin) } \\
\text { (mg/kg feed) }\end{array}$ & $\begin{array}{l}\text { Additive or synergistic } \\
\text { combined effects }^{2}\end{array}$ & Antagonistic combined effect ${ }^{2}$ & Reference \\
\hline MON/FB quail (35 days) & $100 / 200$ & $\begin{array}{l}\text { - body weight } \\
\text { - mortality }\end{array}$ & $\begin{array}{l}\text { - total protein } \\
\text { - cholesterol } \\
\text { - alanine aminotransferase, aspartate } \\
\text { aminotransferase } \\
\text { - albumin } \\
\text { - lactate dehydrogenase, cytokine } \\
\text { - creatinine } \\
\text { - delayed type hyposensitivity reaction }\end{array}$ & $\begin{array}{l}\text { Sharma et al. (2008, } \\
\text { 2012) }\end{array}$ \\
\hline MON/FB fish (70 days) & $\begin{array}{l}40 / 20 \\
40 / 40\end{array}$ & $\begin{array}{l}\text { - size of hepatocyte nuclei } \\
\text { - body weight gain } \\
\text { - serum pyruvate } \\
\text { - size of hepatocyte nuclei } \\
\text { - feed intake }\end{array}$ & $\begin{array}{l}\text { - body weight gain, feed intake } \\
\text { - Sa/So liver }{ }^{4} \\
\text { - Sa/So liver }{ }^{4}\end{array}$ & Yildirim et al. (2000) \\
\hline MON/DON turkey (21 days) & $100 / 20$ & $\begin{array}{l}\text { - feed intake } \\
\text { - globulin } \\
\text { - relative weight (kidney) }\end{array}$ & $\begin{array}{l}\text { - body weight gain } \\
\text { - relative weight (heart) } \\
\text { - calcium }\end{array}$ & Morris et al. (1999) \\
\hline $\begin{array}{l}\text { MON/DON chicken } \\
\text { ( } 21 \text { days) }\end{array}$ & $100 / 16$ & $\begin{array}{l}\text { - feed intake } \\
\text { - relative weight (gizzard and } \\
\text { heart) } \\
\text { - epithelial degeneration }\end{array}$ & & Harvey et al. (1997) \\
\hline
\end{tabular}

The combined effects of $\mathrm{MON} / \mathrm{FB}_{1}$ were studied in chickens by Javed et al. $(1993,1995)$. Six groups of 10 day-old broiler chickens (Columbia $\times$ New Hampshire) were used up to 14 days of age: in addition to the control group, birds were fed diets containing: (a) purified $\mathrm{FB}_{1}$ at $125 \mathrm{mg} / \mathrm{kg}$ feed; (b) purified $\mathrm{FB}_{1}$ at $274 \mathrm{mg} / \mathrm{kg}$ feed; (c) purified $\mathrm{MON}$ at $27 \mathrm{mg} / \mathrm{kg}$ feed; (d) purified $\mathrm{MON}$ at $154 \mathrm{mg} / \mathrm{kg}$ feed; and (e) a diet containing both purified $\mathrm{FB}_{1}$ and $\mathrm{MON}$ in combination at 137 and $77 \mathrm{mg} / \mathrm{kg}$ feed, respectively. No clinical signs or deaths occurred in the controls. Adverse health effects in birds treated with the combination occurred earlier (after 2 days) than in birds treated by MON alone at 154 and $27 \mathrm{mg} / \mathrm{kg}$ feed or $\mathrm{FB}_{1}$ alone at 274 and $125 \mathrm{mg} / \mathrm{kg}$ feed after 5 and 7 days, respectively. These observed effects were ataxia, reduced feed intake, transient increase in water intake and seeking the heat source, and were followed in some birds by weakness and death. At day 10, mortality was $100 \%$ in birds treated with the combination. At day 7, mortality was $79 \%$ in the group with individual $\mathrm{MON}$ at $154 \mathrm{mg} / \mathrm{kg}, 50 \%$ with $\mathrm{FB}_{1}$ at $274 \mathrm{mg} / \mathrm{kg}, 40 \%$ with MON-only at $27 \mathrm{mg} / \mathrm{kg}$, and $20 \%$ with $\mathrm{FB}_{1}$-only at $125 \mathrm{mg} / \mathrm{kg}$. Birds surviving at least 10 to 14 days (the end of treatment) showed lowest weight gain in the combination group. The authors concluded that toxicity of MON and $\mathrm{FB}_{1}$ was additive (Javed et al., 1993). Regarding serohaematological parameters, increased values of alkaline phosphatase, gamma glutamyltransferase, aspartate aminotransferase, alanine aminotransferase, and lactate dehydrogenase activities were observed, and the authors interpreted these elevated activities as being indicative of both hepatic and renal damage. The authors also concluded that the decrease in glucose concentrations resulted from pancreatic damage (Javed et al., 1995). It should be noted that in these studies, which were published in two separate papers (Javed et al., 1993, 1995), the levels of both $\mathrm{MON}$ and $\mathrm{FB}_{1}$ alone were different from the levels of $\mathrm{MON}$ and $\mathrm{FB}_{1}$ in combination.

Since probable organ damage, as interpreted by Javed $e t$ al. (1995), was similar to that associated with vitamin A deficiency, serum vitamin A (retinol) status was studied by Hall et al. (1995) in a follow-up study. Depressed vitamin A concentrations were present in the serum of chicks given a diet supplemented with $\mathrm{FB}_{1}$ and in combination 
with MON (at 137 and $77 \mathrm{mg} / \mathrm{kg}$ feed, respectively) when compared with those fed the MON-only supplemented diet (at $27 \mathrm{mg} / \mathrm{kg}$ feed), or the control diet. The authors concluded that vitamin A deficiency may be associated with organ damage as suggested by Javed et al. (1995) in their previous study. However, it should be noted that also in this study, which used on the same experimental design as those of Javed et al. $(1993,1995)$, the levels of both $\mathrm{FB}_{1}$ and $\mathrm{MON}$ alone were different from the levels of $\mathrm{FB}_{1}$ and $\mathrm{MON}$ in combination. While the levels were similar for $\mathrm{FB}_{1}$ (125 mg/kg feed tested alone versus $137 \mathrm{mg} / \mathrm{kg}$ feed tested in combination), the levels for MON were very different (27 mg/kg feed when tested alone versus $77 \mathrm{mg} / \mathrm{kg}$ when tested in combination).

Consequently, due to this discrepancy in the toxin levels of the experimental design and in particular between the levels of MON tested alone and MON tested in combination, the results of these three studies and the conclusions of the authors of an additive effect in combination, should be interpreted with caution.

Ledoux et al. (2003) conducted a study on the individual and combined effects of $\mathrm{MON}$ and $\mathrm{FB}_{1}$ in broiler chickens in four groups of five birds for 21 days. One group was fed an uncontaminated basal diet as the control. Two groups received a diet contaminated with single $100 \mathrm{mg} \mathrm{MON} /$ $\mathrm{kg}$ feed and $200 \mathrm{mg} \mathrm{FB}_{1} / \mathrm{kg}$ feed, respectively, and a fourth group was fed the combination of $100 \mathrm{mg} \mathrm{MON} / \mathrm{kg}$ and $200 \mathrm{mg} \mathrm{FB} / 1 \mathrm{~kg}$ feed. The level of $100 \mathrm{mg} \mathrm{MON} / \mathrm{kg}$ feed was chosen because it corresponded to the previously identified level which resulted in decreasing body weight gain for chickens (Ledoux et al., 1995). Regarding the level of 200 $\mathrm{mg} \mathrm{FB}_{1} / \mathrm{kg}$, the authors indicated that this was based on available literature data, where mild to moderate toxicosis was observed in chickens fed 75 to $400 \mathrm{mg} \mathrm{FB} / \mathrm{kg}$ feed, with the primary changes being decreased body weight gain and liver lesions. Both $\mathrm{MON}$ and $\mathrm{FB}_{1}$ contaminations were obtained by adding appropriate percentages of ground culture materials of referenced Fusarium strains producing $\mathrm{MON}$ or $\mathrm{FB}_{1}$. Both feed intake and body weight gain were decreased in chickens fed diets containing $100 \mathrm{mg}$ MON/ $\mathrm{kg}$ feed and $\mathrm{FB}_{1}$ as compared with controls. Chickens fed MON had heavier heart weights than control chicks or chicks fed $\mathrm{FB}_{1}$. Compared to the controls, chickens fed diets containing $200 \mathrm{mg} \mathrm{MON} / \mathrm{kg}$ had increased kidney and liver weights. Mild to moderate periportal extramedullary haematopoieses and mild focal hepatic necroses were observed in chicks fed $\mathrm{FB}_{1}$ alone. An increased incidence of large pleomorphic cardiomyocyte nuclei, loss of cardiomyocytes, and mild focal renal tubular mineralisation were observed in chicks fed MON alone. Chickens fed diets containing the combination of $200 \mathrm{mg} \mathrm{FB} / \mathrm{kg}$ and $100 \mathrm{mg}$ $\mathrm{MON} / \mathrm{kg}$ had increased kidney and liver weights and both cardiac and renal lesions were also observed. The authors concluded that MON is much more toxic to broilers than
$\mathrm{FB}_{1}$ at the levels tested and that the combined effects of $\mathrm{MON}$ and $\mathrm{FB}_{1}$ were not synergistic and less than additive.

Kubena et al. (1999) investigated the combined effects of MON and $\mathrm{FB}_{1}$ on White Leghorn laying hens, 24 weeks old at the start of the experiment. MON was supplied by F. fujikuroi culture material, and $\mathrm{FB}_{1}$ was supplied by $F$. moniliforme culture material. Six groups of 6 birds were fed either a control diet, two diets containing MON (50 and $100 \mathrm{mg} / \mathrm{kg}$ feed), two diets containing $\mathrm{FB}_{1}$ (100 and $200 \mathrm{mg} / \mathrm{kg} \mathrm{FB}_{1)}$ and one diet containing a combination of $50 \mathrm{mg} / \mathrm{kg} \mathrm{MON}$ and $100 \mathrm{mg} / \mathrm{kg} \mathrm{FB}$, for 14 months. However, the $100 \mathrm{mg} \mathrm{FB}_{1}$ diet also contained approximately $30 \mathrm{mg} \mathrm{FB}$ and $9 \mathrm{mg} \mathrm{FB}_{3}$, while the $200 \mathrm{mg} \mathrm{FB}_{1} / \mathrm{kg}$ diet also contained $60 \mathrm{mg} \mathrm{FB}$ and $18 \mathrm{mg} \mathrm{FB}_{3}$ per $\mathrm{kg}$ feed. Adverse effects including mortality, reduced egg production and body weight gain were observed only in the group of hens fed $100 \mathrm{mg} / \mathrm{kg}$ MON. No synergy between MON and FB was observed for any of the parameters measured when laying hens were fed the combination of $50 \mathrm{mg} \mathrm{MON}$ and $100 \mathrm{mg} \mathrm{FB}$ per kg feed.

In an experiment carried out by Bermudez et al. (1997) four groups of 20-day old female turkey poults were fed a control ration, or rations containing $100 \mathrm{mg} \mathrm{MON} / \mathrm{kg}$, or $200 \mathrm{mg}$ $\mathrm{FB}_{1} / \mathrm{kg}$, or a combination of $100 \mathrm{mg} \mathrm{MON} / \mathrm{kg}$ and $200 \mathrm{mg}$ $\mathrm{FB}_{1} / \mathrm{kg}$ feed for 21 days. Regarding the chosen levels, the authors reported that $100 \mathrm{mg} \mathrm{MON} / \mathrm{kg}$ feed was identified to cause body weight gain reductions for turkeys, and levels from 75 to $400 \mathrm{mg} \mathrm{FB} / \mathrm{kg}$ feed were known to generate adverse effects to poultry species, such as body weight gain reduction. $\mathrm{MON}$ and $\mathrm{FB}_{1}$ were supplied by $F$. fujikuroi and by $F$. moniliforme culture materials, respectively. Culture materials were included in the basal diet in percentages appropriate to provide the targeted levels of the respective toxins. No treatment-related mortality was observed. In comparison to the controls, turkeys fed $\mathrm{FB}_{1}$ had increased liver weights. Both aspartate aminotransferase and lactate dehydrogenase were increased in poults fed $\mathrm{FB}_{1}$. Turkeys fed MON had decreased feed intake and body weight gains and increased heart weights. Turkeys fed the ration containing both $\mathrm{MON}$ and $\mathrm{FB}_{1}$ had all the above changes; however, no additive or synergistic effects were evident for any single parameter measured. No treatment-related morbidity or mortality was observed in the study (Bermudez et al., 1997).

Sharma et al. (2008) performed an experiment on day-old quail chicks (Coturnix coturnix japonica) until 35 days of age. The control group involved 75 birds, fed quail mash alone, while in each of the treatment groups 105 birds were fed diets containing $100 \mathrm{mg} \mathrm{MON} / \mathrm{kg}$ or $200 \mathrm{mg} \mathrm{FB} / \mathrm{kg}$ feed, or a combination of $100 \mathrm{mg} \mathrm{MON} / \mathrm{kg}$ and $200 \mathrm{mg} \mathrm{FB}_{1} /$ $\mathrm{kg}$ feed. The basal feed was found to contain aflatoxins at $6 \mu \mathrm{g} / \mathrm{kg}$ but not citrinin, $\mathrm{FB}_{1}, \mathrm{MON}$, ochratoxin A, T-2 toxin and zearalenone (ZEA). F. verticillioides culture material containing $\mathrm{FB}_{1}$ (no information on the possible presence of 
$\mathrm{FB}_{2}$ and/or $\mathrm{FB}_{3}$ available) and $F$. fujikuroi culture material containing MON were used in appropriate proportions to achieve the contamination levels of the experimental diets. Birds fed a diet contaminated with $200 \mathrm{mg} \mathrm{FB}_{1} / \mathrm{kg}$ feed showed ruffled feathers and poor growth. Those in the group fed the diet contaminated with $100 \mathrm{mg}$ MON/ $\mathrm{kg}$ feed and in the group fed the $\mathrm{FB}_{1}$ diet exhibited signs of poor feathering and decreased feed intake. Clinical signs observed in the group fed a diet contaminated with $100 \mathrm{mg} \mathrm{MON} / \mathrm{kg}$ and $200 \mathrm{mg} \mathrm{FB} / \mathrm{kg}$ feed were similar to those observed in groups fed the $\mathrm{MON}$ or $\mathrm{FB}_{1}$ diets alone. The mortality throughout the experiment was 7.6\%, 12.4\% and $21 \%$ for groups fed $\mathrm{MON}, \mathrm{FB}_{1}$, and $\mathrm{MON} / \mathrm{FB}_{1}$ diets respectively. The mortality for the group of birds fed with the combination diet $\left(\mathrm{MON} / \mathrm{FB}_{1}\right)$ was higher than the mortality for the group of birds fed single toxin diets, which could indicate an additive effect. In the surviving birds, the reduction of feed intake was comparatively more severe in groups fed either MON diet alone or in combination with $\mathrm{FB}_{1}$ relative to the group fed $\mathrm{FB}_{1}$ diet alone, suggesting that MON was responsible for the reductions in feed intake. Although body weight gains in the MON diet alone and combination groups were lower than in the $\mathrm{FB}_{1}$ alone group, no additive or interactive effects were evident between $\mathrm{FB}_{1}$ and MON. Cell-mediated immune response was more or less comparable in the control and MON treatments. By contrast, throughout the study the presence of $\mathrm{FB}_{1}$, in both the $\mathrm{FB}_{1}$-only and $\mathrm{MON} / \mathrm{FB}_{1}$ groups, was associated with a gradual increase in skin thickness, and a lower mononuclear inflammatory cell response as compared with the control and MON groups. In conclusion, no additive or interactive effects were evident between $\mathrm{MON}$ and $\mathrm{FB}_{1}$ except for mortality and serum aspartate transaminase, where additive effects were observed.

Building on this experiment, Sharma et al. (2012) undertook a subsequent study which focused on gross and microscopic observations reported. Thinning of the heart was the only gross lesion in the group fed $\mathrm{FB}_{1}$ alone, whereas mild-tosevere cardiomegaly was observed both in groups fed $\mathrm{MON}$ alone and in the group fed the combined $\mathrm{MON} / \mathrm{FB}_{1}$ diet. Microscopically, thinning of cardiomyocytes was evident at the $7^{\text {th }}$ day of the experiment in the group fed $\mathrm{FB}_{1}$ alone. In the same study, hypertrophy of cardiomyocytes was noticed in the group fed MON alone. Similar - but more severe - lesions were observed in the group fed the combined $\mathrm{MON} / \mathrm{FB}_{1}$ diet. These included myocardial haemorrhages, vacuolar changes, hypertrophy of cardiomyocytes, focal myocarditis, and loss of myofibrils cross-striations. The authors concluded that the effect of MON on the heart is exaggerated in the presence of $\mathrm{FB}_{1}$. Although the overall interactive effect of $\mathrm{FB}_{1}$ and $\mathrm{MON}$ was less than additive, the interactive effects between the two toxins for cardiac lesions were at least additive and perhaps even synergistic up to the second week.
In a study reported by Yildirim et al. (2000) on fish, 35 Channel catfish (Ictalurus punctatus) were fed a basal diet as control (no information on the possible content of mycotoxins) and diets formulated to contain 20, 40, 60 and $120 \mathrm{mg} \mathrm{MON} / \mathrm{kg} ; 20$ and $40 \mathrm{mg} \mathrm{FB} / \mathrm{kg}$, or two combinations of $\mathrm{MON} / \mathrm{FB}_{1}$, namely $40: 20 \mathrm{mg} / \mathrm{kg}$ and $40: 40 \mathrm{mg} / \mathrm{kg}$, for 10 weeks. F. proliferatum culture material containing MON, and $F$. moniliforme culture material containing $\mathrm{FB}_{1}$ (no information on possible co-occurrence of $\mathrm{FB}_{2}$ and/or $\mathrm{FB}_{3}$ ) were added in the experimental diets at appropriate proportions to achieve the desired contamination levels. Fish fed diets with contamination levels of $20 \mathrm{mg}$ MON alone or $20 \mathrm{mg} \mathrm{FB}_{1}$ alone per $\mathrm{kg}$ feed had statistically lower body weight gains than the fish fed the control diet, while the body weight gain of fish fed the $\mathrm{FB}_{1}$ diet was even lower than that of fish fed the MON diet. An interactive effect from combinations of $\mathrm{MON}$ and $\mathrm{FB}_{1}$ in diets was observed. Fish fed with both the combinations MON/FB $140: 20$ and $40: 40 \mathrm{mg} / \mathrm{kg}$ had lower weight gains than fish fed MON alone and $\mathrm{FB}_{1}$ alone at the same levels. Overall mortality of fish was $4 \%$ and not related to treatment effects. Fish fed diets containing $\mathrm{MON}\left(60 \mathrm{mg} / \mathrm{kg}\right.$ feed) and $\mathrm{FB}_{1}(40 \mathrm{mg} / \mathrm{kg}$ feed), and both combinations of $\mathrm{MON}$ and $\mathrm{FB}_{\mathrm{I}}$ at levels of 40:20 and 40:40 $\mathrm{mg} / \mathrm{kg}$ resulted in significant reductions in haematocrit compared with the control fish. Increases in serum pyruvate concentration were observed with increasing concentrations of dietary $\mathrm{MON}$ and $\mathrm{FB}_{1}$, and both combinations of $\mathrm{MON} / \mathrm{FB}_{1}$ as compared to the control. Dietary levels from $20 \mathrm{mg} \mathrm{FB}_{1} / \mathrm{kg}$ feed caused a significant increase of the ratio of free sphinganine to free sphingosine in Channel catfish liver, while the diets with MON had no influence on this ratio. Also, no interaction due to both combinations of $\mathrm{MON} / \mathrm{FB}_{1}$ was observed since there was no change of the effect of $\mathrm{FB}_{1}$ on this ratio. Altogether, from the five endpoints assessed in this unique study involving fish, only the combined effect of $\mathrm{MON}$ and $\mathrm{FB}_{1}$ on the fish body weight gain gave some indication of an interactive toxicity, although the type of interaction was not indicated.

In summary, the typical experimental design in the publications reporting data on the combined toxicity of MON and $\mathrm{FB}_{1}$ analysed the subacute toxicity induced by $200 \mathrm{mg} \mathrm{FB} / \mathrm{kg}$ diet, or $100 \mathrm{mg} \mathrm{MON} / \mathrm{kg}$ diet, or a combination of the two. These investigations mainly involved poultry and paid attention to the adverse effects on feed intake, weight gain and immune response, as well as organ lesions. Most of the publications concluded an interactive toxicity of $\mathrm{FB}_{1}$ and $\mathrm{MON}$, although for most of the studies the reported experimental design did not allow the type of interaction to be identified. The limited data available would suggest that the combined adverse effects exerted by $\mathrm{FB}_{1}$ and $\mathrm{MON}$ are not synergistic. 


\section{Moniliformin and deoxynivalenol}

MON from culture material and DON from naturally contaminated wheat (no information on occurrence of other mycotoxins given) were used to prepare diets containing $100 \mathrm{mg} \mathrm{MON} / \mathrm{kg}, 16 \mathrm{mg}$ DON $/ \mathrm{kg}$ and a combination of $100 \mathrm{mg} \mathrm{MON} / \mathrm{kg}$ and $16 \mathrm{mg}$ DON/kg fed to 36 one-day-old broiler chickens for 21 days (Harvey et al., 1997). Bodyweight gain and feed consumption were decreased by feeding MON and combined MON/DON diets. Relative heart weight was increased by the MON diet, whereas relative weights of proventriculus, gizzard, and heart were increased by the MON plus DON diet. The MON diet increased alanine transferase and aspartate transaminase activities and creatinine concentration. Histopathological lesions on the MON diet were limited to the kidney and consisted of extensive renal tubular epithelial degeneration plus luminal mineralisation. A moderation of the severity of lesions was seen in the tissues of chickens fed the MON/ DON diet, consisting generally of mild tubular epithelial degeneration. None of the zootechnical and biochemical parameters studied, nor the examined organs and tissues were affected by the DON-only diet. Based on their results, the authors concluded that additive or less-than-additive toxicity was observed when chickens were fed a diet combining $100 \mathrm{mg}$ MON and $16 \mathrm{mg}$ DON per kg feed (Harvey et al., 1997).

In a study reported by Morris et al. (1999) on growing turkey poults, 24 birds were fed a control diet, diets containing $20 \mathrm{mg} \mathrm{DON} / \mathrm{kg}$, or $100 \mathrm{mg} \mathrm{MON} / \mathrm{kg}$, or a combination of $20 \mathrm{mg} / \mathrm{kg}$ DON and $100 \mathrm{mg} \mathrm{MON} / \mathrm{kg}$, from 1 to 21 days of age. DON was semi purified from contaminated barley, and MON was obtained from culture material of F. fujikuroi. Compared with the control group, performance parameters such as feed intake and body weight gains were similar for the birds fed the DON alone diet but were decreased by dietary treatments containing MON alone and containing the combination of both DON and MON. The authors indicated that no interactive effects on performance were evident between MON and DON. Mean cell volume was decreased by the MON and MON/DON treatments, but the decrease was smaller in birds for the combination MON/DON treatment than for the other treatments, resulting in a significant DON $\times$ MON interaction. Mean cell haemoglobin and mean cell haemoglobin concentrations were not affected by any of the dietary treatments. No histological lesions were seen in the control poults or poults fed DON alone, whereas birds fed diets containing MON alone or the MON/DON combination exhibited an increased incidence of variable sized cardiomyocyte nuclei, with numerous large giant nuclei, and a generalised loss of cardiomyocyte cross striations. Isolated renal tubules in sections of kidney were noted to have mild diffuse mineralisation in birds fed MON and the combination MON/DON treatments. However, none of response variables measured were affected by DON alone. The authors concluded that the toxicity of the combination of MON/DON primarily reflected the toxicity of MON and not DON. No toxic synergy was observed when these toxins were fed simultaneously to turkey poults for 21 days (Morris et al., 1999).

The two experimental studies identified for this review examined the subacute combined toxicity of MON and DON for two poultry species for a large panel of endpoints. The study on broiler chickens concluded an additive or less-than-additive toxicity. The study with turkeys did not conclude a toxic synergy effect. Clearly, the body of evidence for a strong interactive toxicity of both mycotoxins remains weak, and further investigations involving this combination of mycotoxins are necessary.

\section{Discussion and conclusions}

Many studies have identified the ability of several fungi belonging to Fusarium species and isolated from naturally contaminated cereal grains to produce both $\mathrm{MON}$ and one or several other toxin(s) including BEA, ENNs and FBs. Many of these grains are widely used in the diets of farm animals. Moreover, different fungal species producing different mycotoxins, such as DON and/or ZEA, can also contaminate grains and consequently these mycotoxins can co-occur with MON in the feeding stuffs. Surveys and monitoring programs have reported these co-occurrences and in particular the presence of MON together with BEA, ENNs, DON and FBs.

The scope of this review was limited to co-occurrence in feed and combined effects in farm animals, because there were no data on combined effects of MON in experimental animals. In the studies reported here the sources of the toxins were either the pure toxin (when it was commercially available or purified from Fusarium culture material) or the Fusarium culture material itself. It should also be noted that the presence of other mycotoxins in the culture material (i.e. that used as a source of MON) was, in most cases, not clearly investigated or reported. In addition, the available information often compiled the outcomes regarding specific endpoints for MON, and specific endpoints for the other combined mycotoxin in the mixture. There were no reports relating to adverse effects resulting from the presence of the two mycotoxins involved in the combination, which makes it difficult to even speculate about the type of interaction occurring for their joint toxicity.

The studies identified for this review from the scientific literature on the combined toxicity of MON and a second mycotoxin allowed only the investigation of the two combinations $\mathrm{MON} / \mathrm{FB}_{1}$ and $\mathrm{MON} / \mathrm{DON}$. No studies were available on the combination of $\mathrm{MON}$ and other Fusarium toxins, such as BEA and/or ENNs, although 
several Fusarium species are able to produce these toxins simultaneously. Supplementary Table S1 indicates the cooccurrence of these toxins in (feed) cereals. Clearly there is a discrepancy between the available toxicological studies concerning $\mathrm{MON}$ in combination with other mycotoxins and the available co-occurrence data of MON and other mycotoxins in the diets of farm animals. This could be due to the commercial availability of pure $\mathrm{FB}_{1}$ and $\mathrm{DON}$ standards and the availability of referenced toxigenic Fusarium strains producing large amounts of $\mathrm{FB}_{1}$ or $\mathrm{DON}$ in culture medium or on grains.

Table 1 indicates the selected publications available from the literature on swine, poultry and fish. Only two experimental studies with poultry examined the toxicity of the combination of MON and DON. In most of the experimental studies on poultry and pigs, the tested levels of MON were $100 \mathrm{mg} / \mathrm{kg}$ feed which corresponds to - or is above - the identified LOAELs in these species. While these MON levels are the most relevant from a toxicological point of view, they are higher than the levels identified from the occurrence database in the EFSA Opinion on MON (EFSA, 2018). It cannot be excluded however, that such high levels would occur in practice, given the fact that these levels were reached in the animal feeds in the reported studies using experimental cultures of toxigenic Fusarium strains such as $F$. verticillioides producing $\mathrm{FB}_{1}$ and F. fujikuroi producing MON.

A rigorous assessment of the interactive toxicity of a mixture is complex; there is overall a methodological gap between the in vitro and in vivo studies exploring the combined toxicity of mycotoxins (Groten et al., 1998; Lei et al., 2013). The classical testing for a possible interaction requires the comparison of the actual effect of the mixture to a theoretically expected no-interaction effect, the socalled additive effect (Alassane-Kpembi et al., 2017a). Prediction of the no-interaction pattern is made based on dose-response experiments for the individual mycotoxins, and some elaborated designs including the factorial designs and other theoretical biology-based approaches have been developed for the purpose. Stronger-than-expected effects indicate synergism, whereas lower-than-expected effects indicate antagonism. By contrast to the well-designed in vitro studies that have been published, the lack of an accurate definition of the additive effect is a frequent shortcoming of in vivo studies on the combined toxicity of mycotoxins, as illustrated by the MON combination studies reported in this review (Alassane-Kpembi et al., 2017b; Grenier et al., 2011).

This review has identified possible interactions between a few Fusarium mycotoxins and their effects on animal health and productivity, and these are summarised in Table 2. However, these conclusions are based on a small number of studies with limited experimental designs. Selection criteria were applied to consider the experimental studies with data providing useful information for the identification of interaction(s) between MON and another Fusarium mycotoxin. The typical experimental design in such studies would involve, in addition to a toxin-free control treatment, three groups of animals to determine the subacute toxicity induced by: (a) one level of MON; (b) one level of only one other Fusarium mycotoxin; and (c) a combination of the two toxins at the same levels as used in treatments (a) and (b). Of course, the feed used as a basal diet as well as the source of $\mathrm{MON}$ and the other toxin should be proven to be free of any other mycotoxin, to avoid any possible interfering activity. At present, the body of evidence for a strong interactive toxicity of studied mycotoxins, such as the combination of $\mathrm{MON}$ and $\mathrm{FB}_{1}$ and the combination of MON and DON, remains weak. Further studies are needed on the combined toxicity of MON with other (Fusarium) mycotoxins, such as ZEA, T-2/HT-2 toxins, BEA and ENNs. Such studies should also be extended to other animal species, such as ruminants, for which cereal grains and their by-products are important feed ingredients.

\section{Supplementary material}

Supplementary material can be found online at https://doi. org/10.3920/WMJ2018.2405.

Table S1. Published European studies (samples taken after 2000) on occurrence of moniliformin in food and feed cereals, with information about other, co-occurring, mycotoxins.

\section{Acknowledgement}

The authors thank Dr. Mari Eskola (affiliated with EFSA until October 2017, currently working with the European Chemicals Agency, Helsinki, Finland), for the suggestion to draft this review, which was a spin-off of the work conducted during the preparation of the EFSA Scientific Opinions on 'Fusarium Toxins'. The authors are also indebted to her helpful comments in the preparation of this paper.

\section{References}

Alassane-Kpembi, I., Schatzmayr, G., Marin, D., Taranu, D., Puel, O. and Oswald, I.P., 2017a. Mycotoxins co-contamination: methodological aspects and biological relevance of combined toxicity studies. Critical Reviews in Food Science and Nutrition 16: 3489-3507.

Alassane-Kpembi, I., Puel, O., Pinton, P., Cossalter, A.M., Chou, T.C. and Oswald, I.P., 2017b. Co-exposure to low doses of the food contaminants deoxynivalenol and nivalenol has a synergistic inflammatory effect on intestinal explants. Archives of Toxicology 91: 2677-2687.

Assunção, R., Silva, M.J. and Alvito, P., 2016. Challenges in risk assessment of multiple mycotoxins in food. World Mycotoxin Journal 9: 791-811. 
Bermudez, A.J., Ledoux, D.R., Rottinghaus, G.E. and Bennett, G.A., 1997. The individual and combined effects of the Fusarium mycotoxins moniliformin and fumonisin $B_{1}$ in turkeys. Avian Diseases 41: 304-311.

Broomhead, J.N., Ledoux, D.R., Bermudez, A.H. and Rottinghaus, G.E., 1996. Effects of Fusarium fujikoroi culture material containing known levels of moniliformin on ducklings. Southern Poultry Science Society Meeting 1996, Abstract S18 - Poultry Science. Available at: https://tinyurl.com/yyff8sv7.

Broomhead, J.N., Ledoux, D.R., Bermudez, A.J. and Rottinghaus, G.E., 2002. Chronic effects of moniliformin in broilers and turkeys fed dietary treatments to market age. Avian Diseases 46: 901-908.

Cole, R.J., Kirksey, J.W., Cutler, H.G., Doupnik, B.L. and Peckham, J.C., 1973. Toxin from Fusarium moniliforme: effects on plants and animals. Science 179: 1324-1326.

Darnetty, T. and Salleh, B., 2013. Toxigenicity of Fusarium species in Gibberella fujikuroi species complex associated with stalk and ear rot disease of corn. International Journal of Phytopathology 2: 147-154.

European Food Safety Authority (EFSA), 2013. International framework dealing with human risk assessment of combined exposure to multiple chemicals. EFSA Journal 11: 3313.

European Food Safety Authority (EFSA), 2018. Scientific Opinion on the risks to human and animal health related to the presence of moniliformin in food and feed. EFSA Journal 16: 5082.

European Food Safety Authority (EFSA), 2019. Guidance on harmonised methodologies for human health, animal health and ecological risk assessment of combined exposure to multiple chemicals. EFSA Journal 17: 5634.

Freayman, S., Croubels, S., Devreese, M. and Antonissen, G., 2017. Emerging Fusarium and Alternaria mycotoxins: occurrence, toxicity and toxicokinetics. Toxins 9: 228.

Fotso, J., Leslie, J.F. and Smith, S., 2002. Production of beauvericin, moniliformin, fusaproliferin, and fumonisins $B_{1}, B_{2}$ and $B_{3}$ by fifteen ex-type strains of Fusarium species. Applied and Environment Microbiology 68: 5195-5197.

Grenier, B. and Oswald, I.P., 2011. Mycotoxin co-contamination of food and feed: meta-analysis of publications describing toxicological interactions. World Mycotoxin Journal 4: 285-313.

Groten, J.P., Tajima, O., Feron, V.J. and Schoen, E.D., 1998. Statistically designed experiments to screen chemical mixtures for possible interactions. Environmental Health Perspective 106, Suppl. 6: 1361-1365

Gruber-Dorninger, C., Novak B., Nagl, V. and Berthiller, F., 2017. Emerging mycotoxins: beyond traditionally determined food contaminants. Journal of Agricultural and Food Chemistry 65: 7052-7070.

Gupta, S., Krasnoff, S.B., Underwood, N.L., Renwick, J.A.A. and Roberts, D.W., 1991. Isolation of beauvericin as an insect toxin from Fusarium semitectum and Fusarium moniliforme var. subglutinans. Mycopathologia 115: 185-189.

Hallas-Møller, M., Nielsen, K.F. and Frisvad, J.C., 2016. Production of the Fusarium mycotoxin moniliformin by Penicillium melanoconidium. Journal of Agricultural and Food Chemistry 64: 4505-4510.
Hall, J.O., Javed, T., Bennett, G.A., Richard, J.L., Dombrink-Kurtzman, M.A., Cote, L.M. and Buck, W.B., 1995. Serum vitamin A (retinol) reduction in broiler chicks on feed amended with Fusarium proliferatum culture material or fumonisin $\mathrm{B} 1$ and moniliformin. Journal of Veterinary Diagnostic Investigation 7: 416-418.

Harvey, R.B., Kubena, L.F., Rottinghaus, G.E., Turk, J.R., Casper, H.H. and Buckley, S.A., 1997. Moniliformin from Fusarium fujikouroi culture material and deoxynivalenol from naturally contaminated wheat incorporated into diets of broiler chicks. Avian Diseases 41: 957-963.

Harvey, R.B., Edrington, T.S., Kubena, L.F., Rottinghaus, G.E., Turk, J.R., Genovese, K.J. and Nisbet, D.J., 2001. Toxicity of moniliformin from Fusarium fujikuroi culture material to growing barrows. Journal of Food Protection 64: 1780-1784.

Harvey, R.B., Edrington, T.S., Kubena, L.F., Rottinghaus, G.E., Turk, J.R., Genovese, K.J., Ziprin, R.L. and Nisbet, D.J., 2002. Toxicity of fumonisin from Fusarium verticillioides culture material and moniliformin from Fusarium fujikuroi culture material when fed singly and in combination to growing barrows. Journal of Food Protection 65: 373-377.

Javed, T., Bennett, G.A., Richard, J.L., Dombrink-Kurtzman, M.A., Cote, L.M. and Buck, W.B., 1993. Mortality in broiler chicks on feed amended with Fusarium proliferatum culture material or with purified fumonisin $B_{1}$ and moniliformin. Mycopathologia 123: 171-183.

Javed, T., Dombrink-Kurtzman, M.A., Richard, J.L., Bennett, G.A., Cote, L.M. and Buck, W.B., 1995. Serohematologic alterations in broiler chicks on feed amended with Fusarium proliferatum culture material or fumonisin $B_{1}$ and moniliformin. Journal of Veterinary Diagnostic Investigation 7: 520-526.

Javed, T., Bunte, R.M., Dombrink-Kurtzman, M.A., Richard, J.L., Bennett, G.A., Cote, L.M. and Buck, W.B., 2005. Comparative pathologic changes in broiler chicks on feed amended with Fusarium proliferatum culture material or purified fumonisin $\mathrm{B}_{1}$ and moniliformin. Mycopathologia 159: 553-564.

Kortenkamp, A., Backhaus, T. and Faust, M., 2009. State of the art report on mixture toxicity. School of Pharmacy, University of London, London, UK, 391 pp.

Kubena, L.F., Harvey, R.B., Buckley, S.A., Bailey, R.H. and Rottinghaus, G.E., 1999. Effects of long-term feeding of diets containing moniliformin, supplied by Fusarium fujikuroi culture material, and fumonisin, supplied by Fusarium moniliforme culture material, to laying hens. Poultry Science 78: 1499-1505.

Ledoux, D.R., Bermudez, A.J., Rottinghaus, G.E. and Broomhead, J., 1995. Effects of feeding Fusarium fujikuroi culture material containing known levels of moniliformin in young broiler chicks. Poultry Science 74: 297-305.

Ledoux, D.R., Broomhead, J.N., Bermudez, A.J. and Rottinghaus, G.E., 2003. Individual and combined effects of the Fusarium mycotoxins fumonisin $\mathrm{B}_{1}$ and moniliformin in broiler chicks. Avian Diseases 47: 1368-1375.

Lei, M., Zhang, N. and Qi, D., 2013. In vitro investigation of individual and combined cytotoxic effects of aflatoxin $B_{1}$ and other selected mycotoxins on the cell line porcine kidney 15 . Experimental and Toxicologic Pathology 65: 1149-1157. 
Leslie, J.F., Marasas, W.F.O., Shephard, G.S., Sydenham, E.W., Stockenholm, S. and Thiel, P.G., 1996. Duckling toxicity and the production of fumonisin and moniliformin by isolates in the $\mathrm{A}$ and $\mathrm{F}$ mating populations of Gibberella fujikuroi (Fusarium moniliforme). Applied and Environmental Microbiology 62: 1182-1187.

Meek, M.E., Boobis, A.R., Crofton, K.M., Heinemeyer, G., Raaij, M.V. and Vickers, C., 2011. Risk assessment of combined exposure to multiple chemicals: a WHO/IPCS framework. Regulatory Toxicology and Pharmacology 60: S1-S14.

Morris, C.M., Ledoux, D.R., Broomhead, J., Bermudez, A., Rottinghaus, G.E. and Logan, A., 1997. Effects of pelleting on the toxicity of moniliformin in ducklings. Abstract of the $86^{\text {th }}$ Annual Meeting of Poultry Science Association. August 3-6, 1997. Georgia, USA.

Morris, C.M., Li, Y.C., Ledoux, D.R., Bermudez, A., Rottinghaus, G.E., 1999. The individual and combined effects of feeding moniliformin, supplied by Fusarium fujikuroi culture material, and deoxynivalenol in young turkey poults. Poultry Science 78: 1110-1115.

Sharma, D., Asrani, R.K., Ledoux, D.R., Jindal, N., Rottinghaus, G.E. and Gupta, V.K., 2008. Individual and combined effects of fumonisin $\mathrm{B}_{1}$ and moniliformin on clinicopathological and cell-mediated immune response in Japanese quail. Poultry Science 87: 1039-1051.
Sharma, D., Asrani, R.K., Ledoux, D.R., Rottinghaus, G.E. and Gupta, V.K., 2012. Toxic interaction between fumonisin $B_{1}$ and moniliformin for cardiac lesions in Japanese quail. Avian Disease 56: 545-554.

Silva, E., Rajapakse, N. and Kortenkamp, A., 2002. Something from 'nothing' - eight weak estrogenic chemicals combined at concentrations below NOECs produce significant mixture effects. Environmental Science and Technology 36: 1751-1756.

Sydenham, E.W., Thiel, P.G. and Vleggaar, R., 1996. Physicochemical data for some selected Fusarium toxins. Journal of AOAC International 79: 1365-1379.

Thiel, P.G., 1978. A molecular mechanism for the toxic action of moniliformin, a mycotoxin produced by Fusarium moniliforme. Biochemical Pharmacology 27: 483-486.

Yildirim, M., Manning, B.B., Lovell, R.T., Grizzle, J.M. and Rottinghaus, G.E., 2000. Toxicity of moniliformin and fumonisin $B_{1}$ fed singly and in combination in diets for young channel catfish Ictalurus punctatus. Journal of the World Aquaculture Society 31: 599-608. 
